\title{
P02-015 - A novel MVK mutation in a child with AA amyloid
}

\author{
A Kolsky', D Rowczenio ${ }^{2}$, H Lachmann², Z Vernerova ${ }^{1}$, F Votava ${ }^{1}$, P Dolezalova ${ }^{3 *}$ \\ From 7th Congress of International Society of Systemic Auto-Inflammatory Diseases (ISSAID) \\ Lausanne, Switerland. 22-26 May 2013
}

\begin{abstract}
Introduction
AA amyloidosis may develop as a consequence of chronic inflammatory conditions including inherited periodic fever syndromes. Mevalonate-kinase (MVK) deficiency (MKD) appears to be the least frequent underlying condition after FMF, TRAPS and CAPS. Moreover, amyloidosis rarely manifests during childhood. We report a case of a small child in whom renal biopsy performed because of the cortico-resistant nephrotic syndrome revealed AA amyloidosis.
\end{abstract}

\section{Case Report}

A 4-years old Caucasian girl with negative family history presented with features of nephrotic syndrome in 1/2011. Over the previous 2 years she had been suffering with recurrent episodes of unexplained fever with pharyngitis and lymphadenitis lasting 3 days in 2-4 weekly intervals and received a putative diagnosis of PFAPA (periodic fever, adenitis, pharyngitis, aphtae) syndrome. Despite the increasing frequency of febrile episodes over the last year investigations aimed at excluding monogenic fevers were not performed. In early 2011 her IgD was normal, IgA mildly increased, serum amyoid A (SAA) fluctuated from normal to $200 \mathrm{mg} / \mathrm{l}$. After the standard corticosteroid (CS) treatment of nephrotic syndrome had failed to induce remission after 6 wks, a renal biopsy revealed AA amyloidosis with focal segmental glomerular and vascular involvement. While genetic analysis was pending, Colchicine was added to the CS treatment followed by daily anakinra injections with good response. After a laborious genetic screening to exclude mutations causing FMF, TRAPS and CAPS, following variants in MVK gene were identified: Mutation V377I and a novel deletion in exon 5 C152WfsX6(c.450_453delGGTG). The latter terminates the protein six amino acids after the deletion occurs,

${ }^{3}$ General University Hospital, Prague, Czech Republic

Full list of author information is available at the end of the article effectively making the protein shorter. Within 6 months of the treatment her proteinuria stabilised at protein/creatinine ratio around $23 \mathrm{mg} / \mathrm{mmol}$ with normal GFR. So far there have been no other signs of organ involvement. Despite ongoing anakinra therapy she continues to have occasional febrile episodes with temporary increase of proteinuria and SAA which remains below $10 \mathrm{mg} / \mathrm{l}$ during afebrile intervals.

\section{Discussion}

MKD/HyperIgD-syndrome has been so far reported in only a few cases of AA-amyloidosis. Our patient has been the youngest one to develop this severe complication. The only other child reported so far was also a compound heterozygote carrying the genotype G326R/V377I. The long-term follow-up with careful SAA serial measurements will tell us more about the prognostic significance of the newly described MVK gene mutation. This case report also underlines the importance of careful differential diagnostic re-evaluation of children presenting with PFAPA-like disease in whom febrile episodes do not show a typical prolongation of afebrile intervals over the time.

\section{Disclosure of interest}

None declared.

\section{Authors' details}

${ }^{1}$ University Hospital Kralovske Vinohrady, Prague, Czech Republic. ${ }^{2}$ National Amyloidosis Centre, UCL Medical School, London, UK. ${ }^{3}$ General University Hospital, Prague, Czech Republic.

Published: 8 November 2013

\footnotetext{
References

1. Lachmann HJ, et al: AA Amyloidosis complicating hyperimmunoglobulinemia $D$ with periodic fever syndrome. A report of two cases. Arthritis Rheum 2006, 54(6):2010-14.

2. Lane $T$, et al: AA amyloidosis complicating the inherited periodic fever syndromes. Arthritis Rheum 2012, doi: 10.1002/art.37827.
} 
3. Yel S, et al: Amyloidosis an a child with hyperimmunoglobulinemia D syndrome. IJKD 2013, 7:70-2.

doi:10.1186/1546-0096-11-S1-A122

Cite this article as: Kolsky et al.: P02-015 - A novel MVK mutation in a

child with AA amyloid. Pediatric Rheumatology 2013 11(Suppl 1):A122.

Submit your next manuscript to BioMed Central and take full advantage of:

- Convenient online submission

- Thorough peer review

- No space constraints or color figure charges

- Immediate publication on acceptance

- Inclusion in PubMed, CAS, Scopus and Google Scholar

- Research which is freely available for redistribution

Submit your manuscript at www.biomedcentral.com/submit
() BioMed Central 